\title{
Susceptibility of Helicobacter pylori and its urease activity to the peroxidase-hydrogen peroxide- thiocyanate antimicrobial system
}

\author{
K. SHIN, K. YAMAUCHI, S. TERAGUCHI, H. HAYASAWA and I. IMOTO* \\ Nutritional Science Laboratory, Morinaga Milk Industry Co. Ltd, 5-1-83 Higashihara, Zama, Kanagawa 228-8583 \\ and*Third Department of Internal Medicine, Mie University School of Medicine, 2-174 Edobashi, Tsu, Mie \\ 514-0001, Japan
}

\begin{abstract}
The susceptibility of Helicobacter pylori to the antimicrobial system involving lactoperoxidase, hydrogen peroxide and thiocyanate was investigated. The inhibitory effect of the system on the urease activity of $\boldsymbol{H}$. pylori, which plays a role in its colonisation of the stomach, was also investigated. Twelve $H$. pylori strains examined, including 10 clinical isolates, were all inhibited by the peroxidase system in brain-heart infusion broth supplemented with fetal calf serum, but to different extents. The killing effect was observed within $3 \mathrm{~h}$. Although bacterial viability recovered afterwards, there was still a clear difference between cultures incubated in the presence of the complete system and control cultures incubated in the absence of lactoperoxidase, after incubation for $24 \mathbf{h}$. The urease activity and viability of $\boldsymbol{H}$. pylori were both inactivated by this system in phosphate buffer. These effects were dependent on the concentrations of both lactoperoxidase and hydrogen peroxide and were abolished by the addition of cysteine. Furthermore, these effects were observed when bovine lactoperoxidase was replaced by recombinant human lactoperoxidase or native or recombinant human myeloperoxidase. The peroxidase system found in saliva and milk may contribute to the host defence against $H$. pylori infection and inhibition of transmission via the oral route.
\end{abstract}

\section{Introduction}

Helicobacter pylori, a spiral-shaped gram-negative bacterium with flagella [1], is the cause of human gastritis, peptic gastric ulcers and duodenal ulcers [2]. Recent epidemiological and animal studies have suggested an association between $H$. pylori and gastric cancer, including adenocarcinoma and gastric lymphoma [2]. The urease produced by $H$. pylori is known to be an essential factor for its colonisation of the stomach [1]. Besides neutralising gastric acid, some other roles of this enzyme in H. pylori colonisation and pathogenesis have been suggested. The hydrolysis of urea by cytoplasmic urease results in energy generation in the form of a proton-motive force which drives flagellar rotation, allowing bacterial motility in the mucus gel layer of the stomach $[1,3]$. The formation of monochloramine from ammonia produced by $H$. pylori urease and neutrophil-derived hypochlorous acid have

Received 18 June 2001; revised version received 17 Sept. 2001, accepted 20 Sept. 2001.

Corresponding author: Dr K. Shin (e-mail: k_shin@, morinagamilk.co.jp). been suggested to play an important role in gastric mucosal injury $[4,5]$. Although the precise route of transmission and the natural reservoir of $H$. pylori remain unknown, recent clinical studies support the existence of gastro-oral and oral-oral pathways of transmission [6]. H. pylori has been isolated successfully from the oral cavity by culture [6]. In a study employing the PCR method in which 42 patients were examined, $H$. pylori DNA was identified in dental plaque of $97 \%$ of the patients and in the saliva of $55 \%$ of the patients, showing a distribution relatively independent of the infection status of the stomach [7].

Human saliva, which continuously bathes the oral mucosa and teeth, contains various antimicrobial factors such as lysozyme, lactoferrin, peroxidases and secretory IgA [8]. Two different haem-containing peroxidases, salivary peroxidase secreted from the salivary gland and myeloperoxidase (MPO) derived from neutrophil polymorphonuclear leucocytes (neutrophils), have been identified in whole saliva $[9,10]$. Recent genetic studies have revealed that salivary peroxidase is another product of the gene encoding lactoperoxidase (LPO) [11-14], a secretory peroxidase 
found in breast milk [15-17]. LPO is a monomeric glycoprotein that varies in molecular mass from c. 80 to $100 \mathrm{kDa}[9,13,15-17] . \quad \mathrm{MPO}$ is a tetrameric glycoprotein consisting of two $59-\mathrm{kDa}$ heavy chains and two $13.5-\mathrm{kDa}$ light chains in its mature form and found in the azurophilic granules of neutrophils [18]. These enzymes catalyse the hydrogen peroxide $\left(\mathrm{H}_{2} \mathrm{O}_{2}\right)$ dependent oxidation of thiocyanate $\left(\mathrm{SCN}^{-}\right)$to yield the hypothiocyanite anion $\left(\mathrm{OSCN}^{-}\right)$with inhibitory activity against a wide variety of micro-organisms including gram-positive and gram-negative bacteria, fungi and viruses [19-23]. The product, $\mathrm{OSCN}^{-}$, reacts with microbial sulph-hydryls [24] and inhibits various cellular processes such as glycolysis [25, 26], membrane transport of sugars and amino acids [27, 28] and respiration $[29,30]$. It has been estimated that human saliva samples under resting and stimulated conditions contain $\mathrm{OSCN}^{-}$at average concentrations of 61 and $34 \mu \mathrm{M}$, respectively [31]. Therefore, it is of interest to study the effects of the peroxidase antimicrobial system, a natural component of secretions such as saliva and milk, against $H$. pylori. This study reports for the first time the influence of the peroxidase $-\mathrm{H}_{2} \mathrm{O}_{2}-\mathrm{SCN}^{-}$ antimicrobial system on the viability and urease activity of $H$. pylori.

\section{Materials and methods}

\section{Bacteria and growth conditions}

H. pylori ATCC 43504 and 43629 were obtained from the American Type Culture Collection (Rockville, MD, USA). Ten different human clinical isolates of $H$. pylori isolated from gastric tissue of $H$. pylori-positive patients treated at Mie University Hospital (Mie, Japan), of which four isolates had been used in a previous study [32], were used. The bacteria were grown either on Trypticase Soy Agar (Becton Dickinson) supplemented with defibrinated horse blood (Nihon Biosupp. Center, Tokyo, Japan) 5\% (TSB) or Brain-Heart Infusion Broth (Difco) supplemented with fetal calf serum (Nihon Biosupp. Center) 5\% (BHIserum). The cultures were incubated at $37^{\circ} \mathrm{C}$ under micro-aerobic conditions $\left(\mathrm{CO}_{2} 10 \%\right)$.

\section{Peroxidases}

LPO purified from bovine milk $\left(\mathrm{A}_{412} / \mathrm{A}_{280}=0.90\right)$ was purchased from Sigma. Native human MPO purified from leucocytes $\left(\mathrm{A}_{430} / \mathrm{A}_{280}=0.73\right)$ was obtained from Athens Research and Technology (Athens, GA, USA). Recombinant human LPO and MPO were expressed in a baculovirus-insect cell system and purified according to the procedure described by Shin et al. [13].

\section{Peroxidase system}

The LPO system composed of bovine LPO $8 \mu \mathrm{g} / \mathrm{ml}$, $0.6 \mathrm{mM} \mathrm{H}_{2} \mathrm{O}_{2}$ and $0.66 \mathrm{mM} \mathrm{SCN}^{-}$was tested to assess its influence on the growth of $H$. pylori in 12-well plates containing BHI-serum broth, with a total volume of $2 \mathrm{ml} /$ well. The wells were inoculated with $H$. pylori cells, precultured in BHI-serum broth, at a cell density of c. $10^{6}$ or $10^{7} \mathrm{cfu} / \mathrm{ml}$. The LPO system was initiated by the addition of $\mathrm{H}_{2} \mathrm{O}_{2}$ to the wells containing all other components pre-warmed to $37^{\circ} \mathrm{C}$. The plates were incubated under micro-aerobic conditions at $37^{\circ} \mathrm{C}$ and the number of viable bacterial cells was determined at indicated times by plating on TSB agar after appropriate dilution in phosphate-buffered saline (PBS; $138 \mathrm{mM} \mathrm{NaCl}, 2.7 \mathrm{mM} \mathrm{KCl}, 10 \mathrm{mM}$ phosphate buffer, $\mathrm{pH}$ 7.4). The colonies formed on the plates were counted after incubation under micro-aerobic conditions at $37^{\circ} \mathrm{C}$ for 4 days. The detection limit in determination of the number of $H$. pylori cells was $\log _{10}$ $1.70 \mathrm{cfu} / \mathrm{ml}$.

\section{Urease activity}

The LPO system with the same composition was also tested to assess its influence on the urease activity of H. pylori in $50 \mathrm{~mm}$ sodium phosphate buffer, $\mathrm{pH}$ 6.6. H. pylori cells were treated at a cell density of $c$. $10^{7} \mathrm{cfu} / \mathrm{ml}$ under micro-aerobic conditions at $37^{\circ} \mathrm{C}$ for $1 \mathrm{~h}$. The reaction of the LPO system was terminated by mixing with an equal volume of $10 \mathrm{~mm}$ sodium azide. Sodium azide added at this concentration did not show any inhibitory effect on the urease activity. As a reference, urease purified from Jack bean (Wako Pure Chemical, Osaka, Japan) was also treated with the system at a concentration of $1 \mathrm{mg} / \mathrm{ml}$. After the treatment, the urease activity in the bacterial suspension or the enzyme solution was determined without any further treatment. Measurement of urease activity was based on the phenol-hypochlorite reaction as described by Takebe and Kobayashi [33]. The activity of urease is expressed as international units (IU), where one unit is defined as the amount of enzyme hydrolysing $1 \mu \mathrm{mol}$ of urea $/ \mathrm{min}$ at $37^{\circ} \mathrm{C}$. The influence of the concentrations of LPO and $\mathrm{H}_{2} \mathrm{O}_{2}$, the influence of cysteine added as L-cysteine hydrochloride monohydrate (Kanto Chemical, Tokyo, Japan) and the effect of replacement of bovine LPO with recombinant human LPO, or native or recombinant human MPO were also examined. The number of viable bacterial cells in the reaction mixture of the peroxidase system was also determined without addition of sodium azide by serially diluting the mixture in PBS and plating the diluted samples on TSB agar as described above.

\section{Results}

\section{Effects of the peroxidase system on the growth of H. pylori}

The $12 \mathrm{H}$. pylori strains examined were all inhibited by the LPO system in BHI-serum broth, but to different extents (Table 1). Among them, clinical isolate no. 32 was most susceptible to the LPO system, as the number of viable bacterial cells was reduced by more than 
Table 1. Effect of the LPO system on the number of $H$. pylori in BHI-serum broth

\begin{tabular}{lcc}
\hline & \multicolumn{2}{c}{ Mean $(\mathrm{SD})$ bacterial number $\left(\log _{10} \mathrm{cfu} / \mathrm{ml}\right)^{*}$} \\
\cline { 2 - 3 } Strain no. & Control & LPO system \\
\hline ATCC 43504 & $7.73(0.02)$ & $6.23(0.33)$ \\
ATCC 43629 & $8.34(0.06)$ & $7.79(0.12)$ \\
Clinical isolates & & \\
2 & $7.90(0.06)$ & $4.86(0.46)$ \\
3 & $8.08(0.07)$ & $7.17(0.15)$ \\
19 & $7.97(0.04)$ & $5.83(0.25)$ \\
32 & $7.98(0.08)$ & $3.18(0.39)$ \\
33 & $8.11(0.03)$ & $5.80(0.16)$ \\
38 & $7.98(0.07)$ & $5.81(0.60)$ \\
A & $7.85(0.22)$ & $6.10(0.14)$ \\
B & $8.10(0.04)$ & $6.54(0.26)$ \\
C & $7.17(0.08)$ & $6.16(0.12)$ \\
D & $7.49(0.03)$ & $4.80(0.78)$ \\
\hline
\end{tabular}

BHI-serum broth was inoculated with $H$. pylori cells at $c$. $10^{7} \mathrm{cfu} / \mathrm{ml}$ in the case of each strain examined and the cultures were incubated with the LPO system composed of bovine LPO $8 \mathrm{mg} / \mathrm{L}, 0.6 \mathrm{mM} \mathrm{H}_{2} \mathrm{O}_{2}$ and $0.66 \mathrm{mM} \mathrm{SCN}^{-}$. After incubation at $37^{\circ} \mathrm{C}$ for $24 \mathrm{~h}$ under micro-aerobic conditions, the number of viable bacteria was compared with that in control cultures incubated under the same conditions in the absence of LPO.

* Results represent the mean (SD) of three experiments.

$\log _{10} 4$ compared with control cells incubated in the absence of LPO. Strain ATCC 43629 was the most resistant, as the number of viable cells was reduced by $\log _{10}<1$. Most $H$. pylori strains other than ATCC 43629 and clinical isolate no. 3 showed lower viability after exposure to the LPO system for $24 \mathrm{~h}$ than that at the time of inoculation, indicating that the LPO system is bactericidal against $H$. pylori.

The type strain ATCC 43504 and clinical isolate no. 19 were used to study the mode of action of the LPO system. The killing effect of the LPO system was observed against both strains within $3 \mathrm{~h}$ and the viability recovered afterwards (Fig. 1). However, the number of viable bacteria in the cultures incubated with the complete system was clearly different from that in control cultures incubated in the presence of $\mathrm{SCN}^{-}$only or in the presence of $\mathrm{LPO}$ and $\mathrm{SCN}^{-}$only for up to $24 \mathrm{~h}$ in the case of strain ATCC 43504 and for up to $48 \mathrm{~h}$ in the case of clinical isolate no. 19. The influence of bacterial inoculum size was investigated with two different inocula, with the same concentration $(0.6 \mathrm{mM})$ of $\mathrm{H}_{2} \mathrm{O}_{2}$ in each instance. The viability of clinical isolate no. 19 was significantly reduced in the presence of $\mathrm{SCN}^{-}$and $\mathrm{H}_{2} \mathrm{O}_{2}$ when an inoculum of $10^{6} \mathrm{cfu} / \mathrm{ml}$ was used (Fig. 1d). However, no such decrease in the viability of this strain in the presence of $\mathrm{SCN}^{-}$and $\mathrm{H}_{2} \mathrm{O}_{2}$ was observed when an inoculum of $10^{7} \mathrm{cfu} / \mathrm{ml}$ was used (Fig. 1c). No inhibition of strain ATCC 43504 was observed at the same concentration of $\mathrm{SCN}^{-}$and $\mathrm{H}_{2} \mathrm{O}_{2}$ with an inoculum of $10^{6}$ or $10^{7} \mathrm{cfu} / \mathrm{ml}$ (Fig. 1a and b).

\section{Effects of the peroxidase system on the urease activity and viability of $H$. pylori in phosphate buffer}

As ammonia was detected in BHI-serum broth at a level that significantly interfered with the urease assay, phosphate buffer was used to assess the effect of the LPO system on the urease activity of $H$. pylori. The urease of $H$. pylori and the urease purified from Jack bean were both almost completely inactivated by the LPO system (Table 2). The inactivation of urease was partially abolished by the addition of cysteine hydrochloride, suggesting that such inactivation is due to the oxidation of functionally important sulph-hydryls of the enzyme. The inactivation of urease by this system was found to be dependent on the concentration of LPO and complete inactivation was achieved at an LPO concentration of $1 \mathrm{mg} / \mathrm{L}$ (Fig. 2a). The inactivation of urease was also found to be dependent on the concentration of $\mathrm{H}_{2} \mathrm{O}_{2}$ and no activity of the $H$. pylori urease or the Jack bean enzyme remained when treated at an $\mathrm{H}_{2} \mathrm{O}_{2}$ concentration of 0.3 and $0.01 \mathrm{mM}$, respectively (Fig. 2b).

H. pylori lost viability in phosphate buffer containing the complete LPO system; the number of viable cells decreased to a level below the detection limit (Table 2). Cysteine hydrochloride protected $H$. pylori from the bactericidal effect of the LPO system, suggesting that the oxidation of bacterial sulph-hydryls by $\mathrm{OSCN}^{-}$ may occur. The killing effect of this system was found to be dependent on the concentration of LPO and the number of viable cells decreased to a level below the detection limit at an LPO concentration of $1 \mathrm{mg} / \mathrm{L}$ (Fig. 2c). The killing effect was also found to be dependent on the concentration of $\mathrm{H}_{2} \mathrm{O}_{2}$ and no viable

Table 2. Effects of the LPO system on the urease activity and viability of $H$. pylori in phosphate buffer

\begin{tabular}{|c|c|c|c|c|c|}
\hline \multirow[b]{2}{*}{ Condition } & \multirow{2}{*}{$\frac{\text { Jack bean }}{\underset{\text { Urease }(\mathrm{mIU} / \mu \mathrm{g}}{\text { protein })^{*}}}$} & \multicolumn{2}{|c|}{ H. pylori ATCC 43504} & \multicolumn{2}{|c|}{ H. pylori no. 19} \\
\hline & & $\begin{array}{c}\text { Urease } \\
\text { (mIU } / 10^{7} \mathrm{cfu} \text { of } \\
\text { inoculum })^{*}\end{array}$ & $\begin{array}{c}\text { Mean }(\mathrm{SD}) \text { bacterial } \\
\text { number }\left(\log _{10} \mathrm{cfu} / \mathrm{ml}\right)^{\dagger}\end{array}$ & $\begin{array}{c}\text { Urease (mIU/ } \\
10^{7} \mathrm{cfu} \text { of } \\
\text { inoculum) }\end{array}$ & $\begin{array}{c}\text { Mean (SD) bacterial } \\
\text { number }\left(\log _{10} \mathrm{cfu} / \mathrm{ml}\right)^{\dagger}\end{array}$ \\
\hline Control & 95.2 & 5.45 & $7.06(0.05)$ & 2.71 & $7.21(0.06)$ \\
\hline LPO system & 0.00 & 0.03 & $<1.70$ & 0.01 & $<1.70 \ldots$ \\
\hline LPO system with cysteine & 100 & 4.33 & $6.97(0.07)$ & 1.42 & $7.09(0.17)$ \\
\hline
\end{tabular}

Jack bean urease at $1 \mathrm{mg} / \mathrm{ml}$ or cells of $H$. pylori ATCC 43504 or clinical isolate no. 19 at $c .10^{7}$ cfu/ml were treated with the LPO system with or without $10 \mathrm{mM}$ cysteine in $50 \mathrm{mM}$ phosphate buffer, $\mathrm{pH} 6.6$, at $37^{\circ} \mathrm{C}$ for $1 \mathrm{~h}$ under micro-aerobic conditions; controls did not contain $\mathrm{H}_{2} \mathrm{O}_{2}$. Urease activity and the number of viable bacteria in the mixture were assayed as described in the text.

${ }^{*}$ Results represent the mean of three experiments.

${ }^{\dagger}$ Results represent the mean (SD) of three experiments. 


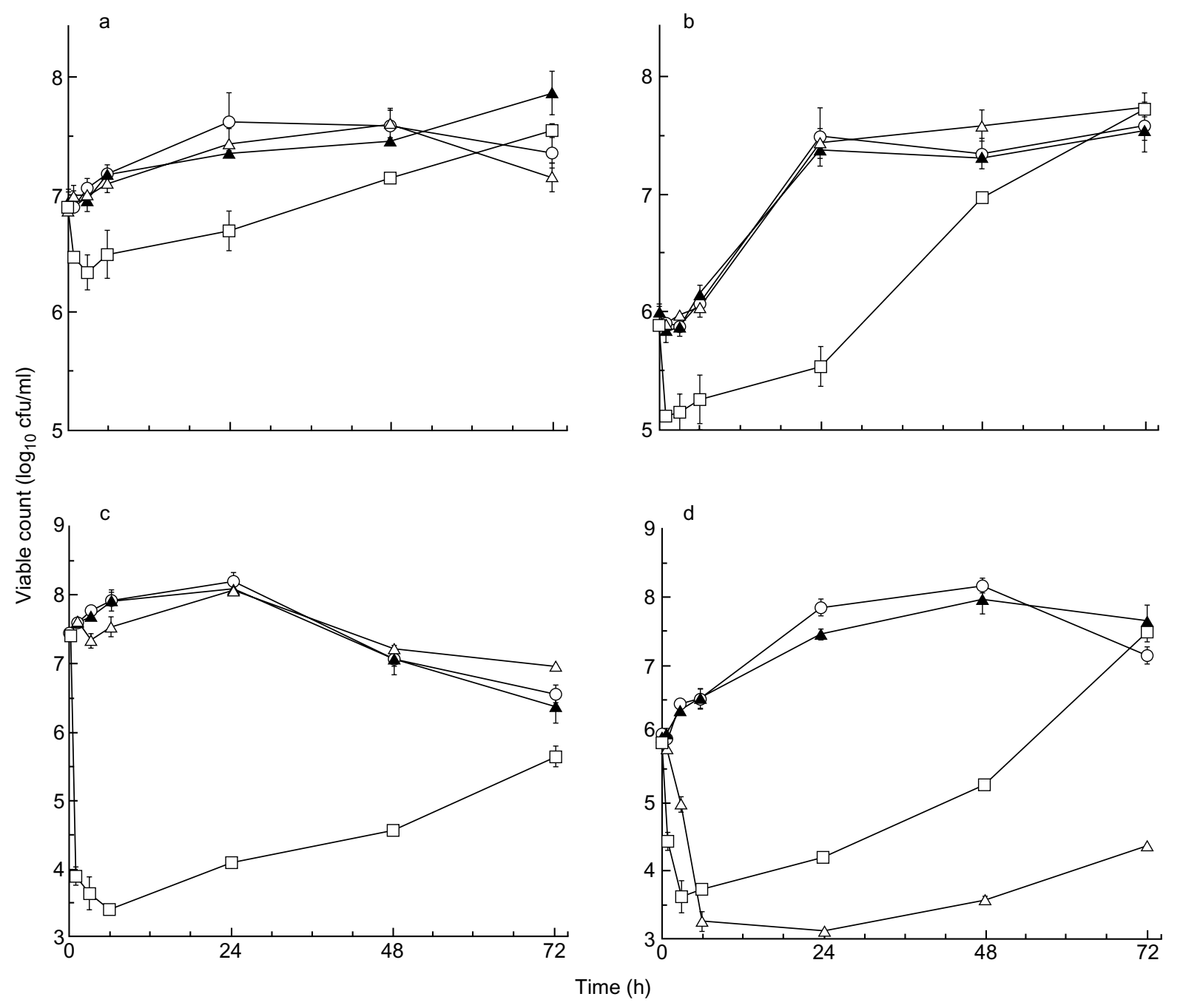

Fig. 1. Antibacterial effect of the LPO system against $H$. pylori in BHI-serum broth. H. pylori ATCC 43504 (a, b) and clinical isolate no. $19(\mathbf{c}, \mathbf{d})$ in BHI-serum broth at initial cell density of $c .10^{7} \mathrm{cfu} / \mathrm{ml}(\mathbf{a}, \mathbf{c})$ or $10^{6} \mathrm{cfu} / \mathrm{ml}(\mathbf{b}, \mathbf{d})$ were incubated with the LPO system composed of bovine LPO $8 \mathrm{mg} / \mathrm{L}, 0.6 \mathrm{mM} \mathrm{H}_{2} \mathrm{O}_{2}$ and $0.66 \mathrm{mM} \mathrm{SCN}^{-}$at $37^{\circ} \mathrm{C}$ under micro-aerobic conditions. The number of viable bacteria was determined at the indicated times. Experiments were carried out with the complete LPO system ( $\square$ ) and with the following components: $\mathrm{SCN}^{-}(\mathrm{O}), \mathrm{LPO}$ and $\mathrm{SCN}^{-}(\boldsymbol{\Delta}), \mathrm{SCN}^{-}$and $\mathrm{H}_{2} \mathrm{O}_{2}(\triangle)$. Results represent the mean of three experiments (bar, SD).

bacteria were found when treated at an $\mathrm{H}_{2} \mathrm{O}_{2}$ concentration of $0.6 \mathrm{~mm}$ (Fig. 2d).

\section{Effects of peroxidases from different sources}

Inhibitory effects of the peroxidase system on the urease activity and viability of $H$. pylori were observed in phosphate buffer when bovine LPO was replaced by recombinant human LPO, or native or recombinant human MPO (Table 3).

\section{Discussion}

The results of the present study show that the system composed of peroxidase, $\mathrm{H}_{2} \mathrm{O}_{2}$ and $\mathrm{SCN}^{-}$, which is a natural component of secretions such as saliva and milk, exerts antimicrobial effects against $H$. pylori. The short-lived bactericidal effect of the system on $H$. pylori is in agreement with previous reports of studies with other species of bacteria, in which $\mathrm{H}_{2} \mathrm{O}_{2}$ was introduced only at the initiation of the reaction [34, 35]. $\mathrm{SCN}^{-}$was used at a concentration of $0.66 \mathrm{mM}$ throughout this study. This concentration of $\mathrm{SCN}^{-}$is within the range reported in human saliva samples $(1.21 \pm 0.66 \mathrm{~m}$ for resting condition and $0.84 \pm 0.48 \mathrm{~m}$ for stimulated condition) [31]. In a previous study, it was observed that the LPO system with a composition similar to that used in this study $\left(0.66 \mathrm{mM} \mathrm{SCN}^{-}\right.$, $0.6 \mathrm{mM} \mathrm{H} \mathrm{H}_{2} \mathrm{O}_{2}$ and bovine LPO $8 \mathrm{mg} / \mathrm{L}$ in $50 \mathrm{mM}$ phosphate buffer, $\mathrm{pH}$ 6.6) yielded $\mathrm{OSCN}^{-}$at concentrations of 171 and $48 \mu \mathrm{M}$ at 5 and $60 \mathrm{~min}$ after the start of the reaction, respectively [30]. These concentrations of $\mathrm{OSCN}^{-}$are also within the range of that reported in human parotid saliva samples collected directly from Stensen's duct (range 10-210 $\mu \mathrm{M}$, av- 

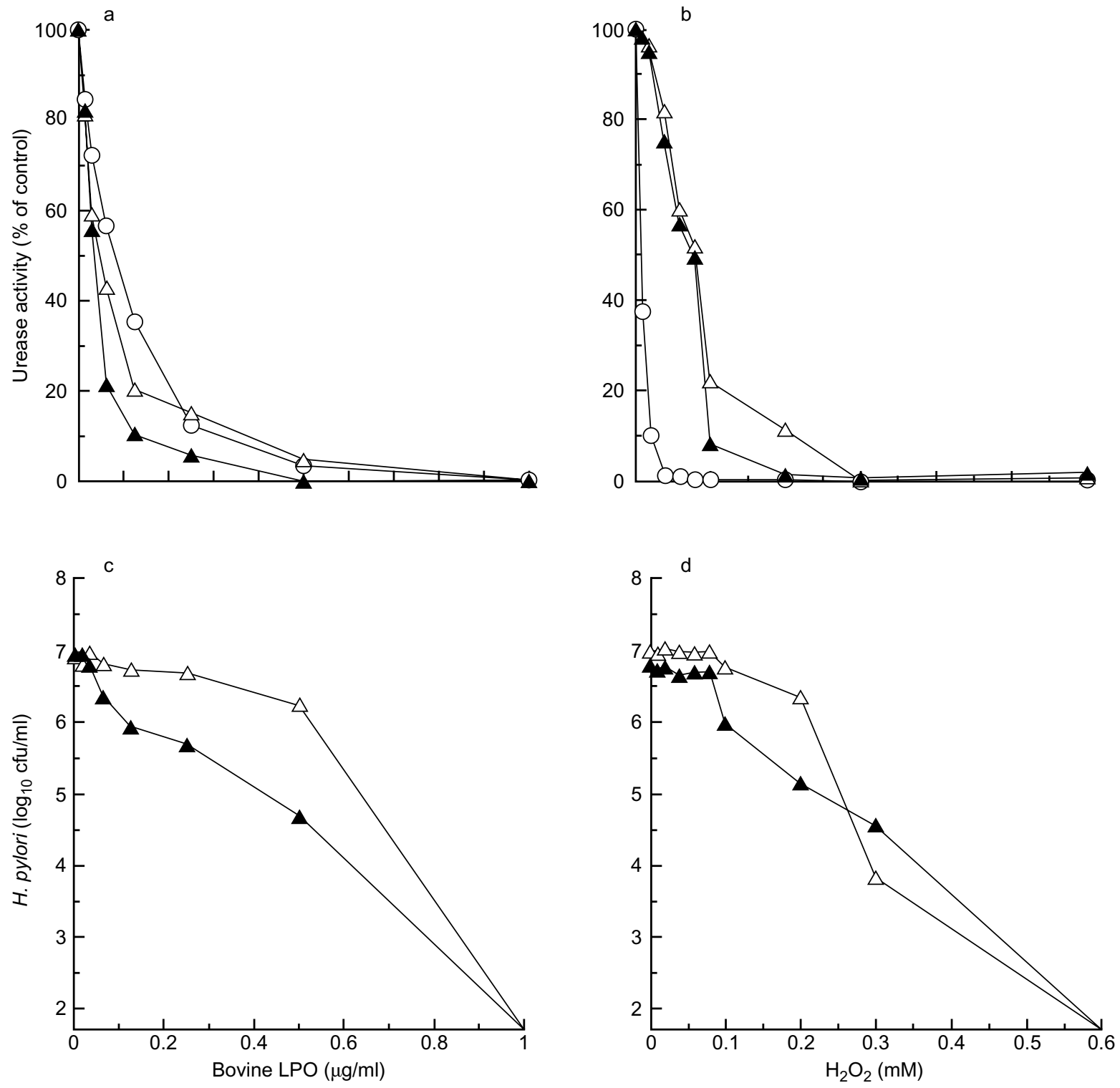

Fig. 2. Influence of the concentrations of LPO and $\mathrm{H}_{2} \mathrm{O}_{2}$ on inactivation of urease and their bactericidal effect against $H$. pylori. Jack bean urease at $1 \mathrm{mg} / \mathrm{ml}(\bigcirc)$ or cells of $H$. pylori ATCC $43504(\triangle)$ or clinical isolate no. $19(\mathbf{\Delta})$ at $c .10^{7} \mathrm{cfu} / \mathrm{ml}$ were treated with the LPO system composed of various concentrations of bovine $\mathrm{LPO}, 0.6 \mathrm{mM} \mathrm{H}_{2} \mathrm{O}_{2}$ and $0.66 \mathrm{mM} \mathrm{SCN}^{-}$in $50 \mathrm{mM}$ phosphate

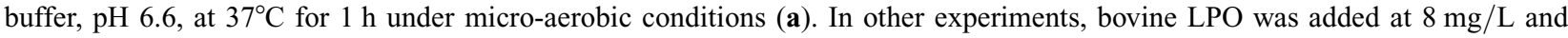
$\mathrm{H}_{2} \mathrm{O}_{2}$ was added at various concentrations (b). Urease activity was assayed as described in the text. Bacterial viability was examined under the same conditions as indicated for panels $\mathbf{a}$ and $\mathbf{b}$ and the results are shown in panels $\mathbf{c}$ and $\mathbf{d}$, respectively. Results represent the mean of two experiments.

Table 3. Effects of LPO and MPO from different sources on the urease activity and viability of $H$. pylori in phosphate buffer

\begin{tabular}{|c|c|c|c|c|}
\hline \multirow[b]{2}{*}{ Peroxidase } & \multicolumn{2}{|c|}{ H. pylori ATCC 43504} & \multicolumn{2}{|c|}{ H. pylori no. 19} \\
\hline & $\begin{array}{l}\text { Urease (mIU/107 } \\
\text { cfu of inoculum) }\end{array}$ & $\begin{array}{c}\text { Mean (SD) bacterial } \\
\text { number }\left(\log _{10} \mathrm{cfu} / \mathrm{ml}\right)^{\dagger}\end{array}$ & $\begin{array}{l}\text { Urease (mIU/10 } / 10^{7} \\
\text { cfu of inoculum)* }\end{array}$ & $\begin{array}{c}\text { Mean (SD) bacterial } \\
\text { number }\left(\log _{10} \mathrm{cfu} / \mathrm{ml}\right)^{\dagger}\end{array}$ \\
\hline Bovine LPO & 0.01 & $<1.70$ & 0.02 & $<1.70$ \\
\hline Recombinant human LPO & 0.00 & $<1.70$ & 0.01 & $<1.70$ \\
\hline Human MPO & 0.00 & $<1.70 \ldots$ & 0.01 & $<1.70 \ldots$ \\
\hline Recombinant human MPO & 0.00 & $2.22(0.20)$ & 0.00 & $<1.70 \ldots$ \\
\hline Control (without peroxidase) & 4.09 & $7.06(0.05)$ & 1.88 & $7.33(0.04)$ \\
\hline
\end{tabular}

Experiments were done under the same conditions as described in Table 2 except that bovine LPO was replaced with recombinant human LPO, or native or recombinant human MPO at the same concentration; controls did not contain peroxidase.

* Results represent the mean of three experiments.

${ }^{\dagger}$ Results represent the mean (SD) of three experiments. 
erage $52 \mu \mathrm{M})$ [31]. Therefore, it seems reasonable to extrapolate the results obtained in this study to the conditions in vivo.

It is well known that $\mathrm{H}_{2} \mathrm{O}_{2}$ in itself has an inhibitory effect on various micro-organisms including $H$. pylori $[36,37]$. Indeed, the viability of clinical isolate no. 19 was significantly reduced in the presence of $0.66 \mathrm{mM}$ $\mathrm{SCN}^{-}$and $0.6 \mathrm{mM} \mathrm{H}_{2} \mathrm{O}_{2}$ when the strain was inoculated at a lower density $\left(10^{6} \mathrm{cfu} / \mathrm{ml}\right)$. As $H$. pylori is catalase positive [38] and not susceptible to $\mathrm{SCN}^{-}$at the concentration used in this study, a larger amount of endogenous catalase from the higher density of cells $\left(10^{7} \mathrm{cfu} / \mathrm{ml}\right)$ may be needed to diminish the toxicity of $\mathrm{H}_{2} \mathrm{O}_{2}$ in the case of a strain with high $\mathrm{H}_{2} \mathrm{O}_{2}$ sensitivity such as clinical isolate no.19. However, most of the results in this study showed that the antimicrobial activity of the product of the reactions catalysed by peroxidases was greater than that of $\mathrm{SCN}^{-}$and $\mathrm{H}_{2} \mathrm{O}_{2}$.

The results of the present study show that the peroxidase system inactivates ureases from $H$. pylori and Jack bean. It has been shown that the chemical modification of a cysteine residue near the active site of the urease from Jack bean, or that of Klebsiella aerogenes, can eliminate enzyme activity [39,40]. A high degree of similarity in the primary structure has been found by comparing the ureases from various bacteria, including $H$. pylori and $K$. aerogenes, and the Jack bean urease [41]. Therefore, it seems reasonable to assume that $\mathrm{OSCN}^{-}$, a reactive intermediate produced by the peroxidase system, inactivates the urease of $H$. pylori and that of Jack bean by reacting with an important cysteine residue near the active site. The influence of the LPO system on urease activity of strains ATCC 43629 and clinical isolate no. 3, which were the most resistant to the system in BHI-serum broth, was also examined. The sensitivity of ureases of these strains was quite similar to that observed for ATCC 43504 and clinical isolate no.19 (details not shown). Therefore, urease inactivation by the LPO system is not likely to correlate directly to the bactericidal effect of the system. Although the urease of H. pylori is principally involved in neutralising gastric acid, recent studies have suggested some other roles of this enzyme in H. pylori colonisation and pathogenesis, such as a role in flagellar rotation and a role in triggering gastric mucosal injury through the inflammatory response $[1,3-5]$. The peroxidase system in secretions may reduce the degree of pathogenesis of $H$. pylori by inhibiting the urease.

Recent genetic studies have demonstrated that salivary peroxidase is expressed from the chromosomal gene encoding LPO [11-14]. The peroxidase system may exert its antimicrobial effect on $H$. pylori in the oral cavity, as whole human saliva contains large amounts of LPO and MPO at average concentrations of 1.9 and $3.6 \mathrm{mg} / \mathrm{L}$ [10], respectively. The concentration of peroxidases, $8 \mathrm{mg} / \mathrm{L}$, used in most of the experiments of this study is slightly above the sum of LPO and MPO concentrations reported in saliva [10] and it is within the range of total peroxidase estimated in saliva with bovine LPO as a standard [42]. The influence of the LPO concentration was tested and it was found that LPO in amounts as small as $1 \mathrm{mg} / \mathrm{L}$ completely abolished both urease activity and the viability of $H$. pylori in phosphate buffer. Furthermore, saliva contains $\mathrm{OSCN}^{-}$, the antimicrobial intermediate produced by the system, at an average concentration ranging from 34 to $61 \mu \mathrm{M}[8,31]$. Although the formation of hypochlorous acid by neutrophil-derived MPO has been suggested to serve as a pathogenic factor of $H$. pylori causing gastric mucosal injury through an inflammatory response $[4,5]$, the system composed of MPO, $\mathrm{H}_{2} \mathrm{O}_{2}$ and $\mathrm{SCN}^{-}$kills the bacteria and can at least contribute to host protection against $H$. pylori in the early stage of infection. The peroxidase system derived from saliva or milk may be active in the oesophagus and the stomach, as it has been shown that peroxidase activity is not rapidly inactivated in gastric juice [43]. Further clinical studies will be needed to determine the influence of the peroxidase system on $H$. pylori colonisation.

We thank Professor Bo Lönnerdal, Department of Nutrition, and Professor Bruce D. Hammock, Department of Entomology, University of California, Davis, for guidance during the production of recombinant peroxidases.

\section{References}

1. Yoshiyama H, Nakazawa T. Unique mechanism of Helicobacter pylori for colonizing the gastric mucus. Microb Infect 2000; 2: 55-60.

2. Ernst PB, Gold BD. The disease spectrum of Helicobacter pylori: the immunopathogenesis of gastroduodenal ulcer and gastric cancer. Annu Rev Microbiol 2000; 54: 615-640.

3. Nakamura H, Yoshiyama H, Takeuchi H, Mizote T, Okita K, Nakazawa T. Urease plays an important role in the chemotactic motility of Helicobacter pylori in a viscous environment. Infect Immun 1998; 66: 4832-4837.

4. Dekigai H, Murakami M, Kita T. Mechanism of Helicobacter pylori-associated gastric mucosal injury. Dig Dis Sci 1995; 40: $1332-1339$.

5. Suzuki M, Miura S, Suematsu M et al. Helicobacter pyloriassociated ammonia production enhances neutrophil-dependent gastric mucosal cell injury. Am J Physiol 1992; 263: G719-G725.

6. Thomas E, Jiang C, Chi DS, Li C, Ferguson DA. The role of the oral cavity in Helicobacter pylori infection. $\mathrm{Am} \mathrm{J}$ Gastroenterol 1997; 92: 2148-2154.

7. Song Q, Lange T, Spahr A, Adler G, Bode G. Characteristic distribution of pattern of Helicobacter pylori in dental plaque and saliva detected with nested PCR. J Med Microbiol 2000; 49: $349-353$.

8. Tenovuo J, Lehtonen O-PJ, Aaltonen AS, Vilja P, Tuohimaa P. Antimicrobial factors in whole saliva of human infants. Infect Immun 1986; 51: 49-53.

9. Mansson-Rahemtulla B, Rahemtulla F, Baldone DC, Pruitt KM, Hjerpe A. Purification and characterization of human salivary peroxidase. Biochemistry 1988; 27: 233-239.

10. Thomas EL, Jefferson MM, Joyner RE, Cook GS, King CC. Leukocyte myeloperoxidase and salivary lactoperoxidase: identification and quantitation in human mixed saliva. $J$ Dent Res 1994; 73: 544-555.

11. Dull TJ, Uyeda C, Strosberg AD, Nedwin G, Seilhamer JJ. Molecular cloning of cDNAs encoding bovine and human lactoperoxidase. DNA Cell Biol 1990; 9: 499-509. 
12. Kiser C, Caterina CK, Engler JA, Rahemtulla B, Rahemtulla F. Cloning and sequence analysis of the human salivary peroxidase-encoding cDNA. Gene 1996; 173: 261-264.

13. Shin K, Hayasawa H, Lönnerdal B. PCR cloning and baculovirus expression of human lactoperoxidase and myeloperoxidase. Biochem Biophys Res Commun 2000; 271: $831-836$.

14. Ueda T, Sakamaki K, Kuroki T, Yano I, Nagata S. Molecular cloning and characterization of the chromosomal gene for human lactoperoxidase. Eur J Biochem 1997; 243: 32-41.

15. Langbakk B, Flatmark T. Lactoperoxidase from human colostrum. Biochem J 1989; 259: 627-631.

16. Pruitt KM, Rahemtulla F, Mansson-Rahemtulla B, Baldone DC, Laven GT. Peroxidases in human milk. Adv Exp Med Biol 1991; 310: 137-144.

17. Shin K, Hayasawa H, Lönnerdal B. Purification and quantification of lactoperoxidase in human milk with use of immunoadsorbents with antibodies against recombinant human lactoperoxidase. Am J Clin Nutr 2001; 73: 984-989.

18. Klebanoff SJ. Myeloperoxidase: occurrence and biological function. In: Everse J, Everse KE, Grisham MB (eds) Peroxidases in chemistry and biology, vol. 1. Boca Raton, CRC Press. 1991: 1-35.

19. Aune TM, Thomas EL. Accumulation of hypothiocyanite ion during peroxidase-catalyzed oxidation of thiocyanate ion. Eur $J$ Biochem 1977; 80: 209-214.

20. Oram JD, Reiter B. The inhibition of streptococci by lactoperoxidase, thiocyanate and hydrogen peroxide. The oxidation of thiocyanate and the nature of the inhibitory compound. Biochem J 1966; 100: 382-388.

21. Pourtois M, Binet C, Van Tieghem N, Courtois P, Vandenabbeele A, Thiry L. Inhibition of HIV infectivity by lactoperoxidase-produced hypothiocyanite. J Biol Buccale 1990; 18: 251-253.

22. Pruitt KM, Reiter B. Biochemistry of peroxidase system: antimicrobial effects. In: Pruitt KM, Tenovuo JO (eds) The lactoperoxidase system: chemistry and biological significance. New York, Marcel Dekker. 1985: 143-178.

23. Reiter B, Perraudin J-P. Lactoperoxidase: biological functions. In: Everse J, Everse KE, Grisham MB (eds) Peroxidases in chemistry and biology, vol. 1. Boca Raton, CRC Press. 1991: 143-180.

24. Thomas EL, Aune TM. Lactoperoxidase, peroxide, thiocyanate antimicrobial system: correlation of sulfhydryl oxidation with antimicrobial action. Infect Immun 1978; 20: 456-463.

25. Adamson M, Pruitt KM. Lactoperoxidase-catalyzed inactivation of hexokinase. Biochim Biophys Acta 1981; 658: 238-247.

26. Hamon CB, Klebanoff SJ. A peroxidase-mediated, Streptococcus mitis-dependent antimicrobial system in saliva. J Exp Med 1973; 137: 438-450

27. Loimaranta V, Tenovuo J, Korhonen H. Combined inhibitory effect of bovine immune whey and peroxidase-generated hypothiocyanite against glucose uptake by Streptococcus mutans. Oral Microbiol Immunol 1998; 13: 378-381.

28. Mickelson MN. Glucose transport in Streptococcus agalactiae and its inhibition by lactoperoxidase-thiocyanate-hydrogen peroxide J Bacteriol 1977; 132: 541-548.

29. Law BA, John P. Effect of the lactoperoxidase bactericidal system on the formation of the electrochemical proton gradient in E. coli. FEMS Microbiol Lett 1981; 10: 67-70.

30. Shin K, Hayasawa H, Lönnerdal B. Inhibition of Escherichia coli respiratory enzymes by the lactoperoxidase-hydrogen peroxide-thiocyanate antimicrobial system. J Appl Microbiol 2001; 90: 489-493.

31. Pruitt KM, Mansson-Rahemtulla B, Tenovuo J. Detection of the hypothiocyanite $\left(\mathrm{OSCN}^{-}\right)$ion in human parotid saliva and the effect of $\mathrm{pH}$ on $\mathrm{OSCN}^{-}$generation in the salivary peroxidase antimicrobial system. Arch Oral Biol 1983; 28: 517-525.

32. Yamazaki N, Yamauchi K, Kawase K, Hayasawa H, Nakao K, Imoto I. Antibacterial effects of lactoferrin and a pepsingenerated lactoferrin peptide against Helicobacter pylori in vitro. J Infect Chemother 1997; 3: 85-89.

33. Takebe S, Kobayashi K. Acid urease from Lactobacillus of rat intestine. Chem Pharm Bull 1988; 36: 693-699.

34. Dionysius DA, Grieve PA, Vos AC. Studies on the lactoperoxidase system: reaction kinetics and antibacterial activity using two methods for hydrogen peroxide generation. $J$ Appl Bacteriol 1992; 72: 146-153.

35. Wolfson LM, Sumner SS. Antibacterial activity of the lactoperoxidase system against Salmonella typhimurium in the trypticase soy broth in the presence and absence of a heat treatment. J Food Protect 1994; 57: 365-368.

36. Murano A, Miyake M, Kato J, Tanzawa H, Takeo K, Noda M. Enhancement of the growth of Helicobacter pylori in Brucella broth by hydrogen peroxide. Microbiol Immunol 1999; 43: 1009-1015.

37. Pericone CD, Overweg K, Hermans PWM, Weiser JN. Inhibitory and bactericidal effects of hydrogen peroxide production by Streptococcus pneumoniae on other inhabitants of the upper respiratory tract. Infect Immun 2000; 68: 3990-3997.

38. Hazell SL, Evans DJ, Graham DY. Helicobacter pylori catalase. J Gen Microbiol 1991; 137: 57-61.

39. Takishima K, Suga T, Mamiya G. The structure of Jack bean urease. The complete amino acid sequence, limited proteolysis and reactive cysteine residues. Eur J Biochem 1988; 175: $151-165$.

40. Todd MJ, Hausinger RP. Reactivity of the essential thiol of Klebsiella aerogenes urease. Effect of $\mathrm{pH}$ and ligands on thiol modification. J Biol Chem 1991; 266: 10260-10267.

41. Mobley HLT, Island MD, Hausinger RP. Molecular biology of microbial ureases. Microbiol Rev 1995; 59: 451-480.

42. Rudney JD, Krig MA, Neuvar EK, Soberay AH, Iverson L. Antimicrobial proteins in human unstimulated whole saliva in relation to each other, and to measures of health status, dental plaque accumulation and composition. Arch Oral Biol 1991; 36: $497-506$.

43. Gothefors L, Marklund S. Lactoperoxidase activity in human milk and in saliva of newborn infants. Infect Immun 1975; 11: $1210-1215$ 